\title{
Epidemiological findings of ocular trauma in childhood
}

\author{
Achados epidemiológicosdo trauma ocular na infância
}

\author{
Angelino Julio Cariello ${ }^{1}$ \\ Nilva Simerem Bueno Moraes ${ }^{2}$ \\ Somaia Mitne ${ }^{3}$ \\ Celina Shizuka Oita ${ }^{4}$ \\ Bruno Machado Fontes 5 \\ Luiz Alberto Soares Melo Jr'
}

\begin{tabular}{l} 
ABSTRACT \\
\hline Purpose: To describe epidemiological findings of ocular trauma in \\
childhood in an emergency unit. Methods: A retrospective study was \\
carried out including patients under 16 years old who were treated for \\
ocular trauma at the emergency unit of the Federal University of São \\
Paulo from September 2001 to September 2004. Age, sex, involved eye, \\
place, circumstance and mechanism of injury, initial visual acuity and \\
immediate management were recorded. Results: A total of 273 patients \\
were included in the study. The age group comprising most cases was \\
7 to 10 years (39.9\%). The most frequent cause of ocular injury was \\
traumatism by external agents like stone, iron and wood objects (27.9\%). \\
The commonest place was the home (53.1\%). Initial visual acuity was \\
over 20/40 in 63.4\% of cases. Closed globe injury occurred in 201 (73.6\%) \\
accidents. Seventy-six children (27.8\%) were treated with medicines and \\
in forty-eight (17.6\%) cases surgery was necessary. Conclusion: Ocular \\
trauma in childhood was more frequent in the male schoolchild and was \\
due mostly to traumatism with agents like stone, wood and iron pieces, \\
domestic utensils and leisure objects. The injuries occurred most fre- \\
quently at home. Closed globe injuries predominated. Programs of \\
education and prevention for ocular trauma in childhood are necessary.
\end{tabular}

Keywords: Eye injuries/epidemiology; Childhood; Eye injuries, penetrating; Emergency service, hospital

\section{INTRODUCTION}

da Universidade Federal de São Paulo - UNIFESP - Sã Paulo (SP) - Brazil.

${ }^{1}$ Medical resident in ophthalmology - Department of Ophthalmology, Universidade Federal de São Paulo UNIFESP - São Paulo (SP) - Brazil.

${ }^{2}$ Head of the Retina Service and Emergency Room Department of Ophthalmology - UNIFESP - São Paulo (SP) - Brazil.

${ }^{3}$ Head of the Trauma Division - Department of Ophthalmology - UNIFESP - São Paulo (SP) - Brazil.

${ }^{4}$ Post graduate student of administration in ophthalmology - UNIFESP - São Paulo (SP) - Brazil.

${ }^{5}$ Medical resident in ophthalmology - Department of Ophthalmology - UNIFESP - São Paulo (SP) - Brazil.

${ }^{6}$ Post graduate student of Glaucoma Service - Department of Ophthalmology - UNIFESP - São Paulo (SP) Brazil.

Address for correspondence: Angelino Julio Cariello. Rua Botucatu, 820 - São Paulo (SP) ZIP 04023-062

E-mail: angelino65@yahoo.com

Recebido para publicação em 29.06.2005

Última versão recebida em 05.11.2005

Aprovação em 26.10.2006

Financial support and proprietary interest: None.

Nota Editorial: Depois de concluída a análise do artigo sob sigilo editorial e com a anuência da Dra. Norma Helen Medina sobre a divulgação de seu nome como revisor, agradecemos sua participação neste processo.

\footnotetext{
Ophthalmic trauma is a leading cause of acquired unilateral blindness in childhood $^{(1)}$, being responsible for up to one third of cases of vision loss in the first decade of life ${ }^{(2)}$. Most injured children have normal vision before the accident and many of the injuries lead to permanent visual $\operatorname{loss}^{(3)}$. Ocular trauma has been an important cause of hospitalization in pediatric patients and corresponds to a significant amblyopic inductor factor ${ }^{(4-5)}$.

In the world population, it has been estimated that there are approximately 1.6 million cases of blindness, 2.3 million cases of low vision and 19 million cases of monocular blindness due to eye injuries ${ }^{(6)}$. Such injuries cannot always be prevented, but by identifying underlying factors in their etiology, it may be possible to determine the most effective methods of reducing the incidence of visually damaging trauma ${ }^{(6)}$.

Epidemiological data about ocular trauma in childhood in developing countries are very scarce ${ }^{(6)}$. The characteristics of children at risk, the agents of injury, and the environmental determinants of ocular trauma must be identified so that appropriate preventive measures can be recommended.

The purpose of this study is to describe the epidemiological findings of ocular trauma in childhood in an emergency unit of a referral ophthalmologic service.
} 


\section{METHODS}

The records of all children under 16 years old treated for ocular trauma from September 2001 to September 2004 in the emergency room of the Department of Ophthalmology of Federal University of São Paulo were reviewed. The following data were recorded: age, sex, date and local of injury, involved eye, circumstance and mechanism of injury, initial visual acuity and immediate management. Ages were ranged into four groups: infants (under 2 years), preschoolers (from 2 to 6 years), schoolchildren (from 7 to 10 years) and adolescents (from 11 to 15 years old) ${ }^{(7)}$. Data underwent descriptive analyses and diagnosis classification according to The Ocular Trauma Classification Group ${ }^{(8)}$. This classification was modified by addition of trauma restricted to eyelids (Table 1).

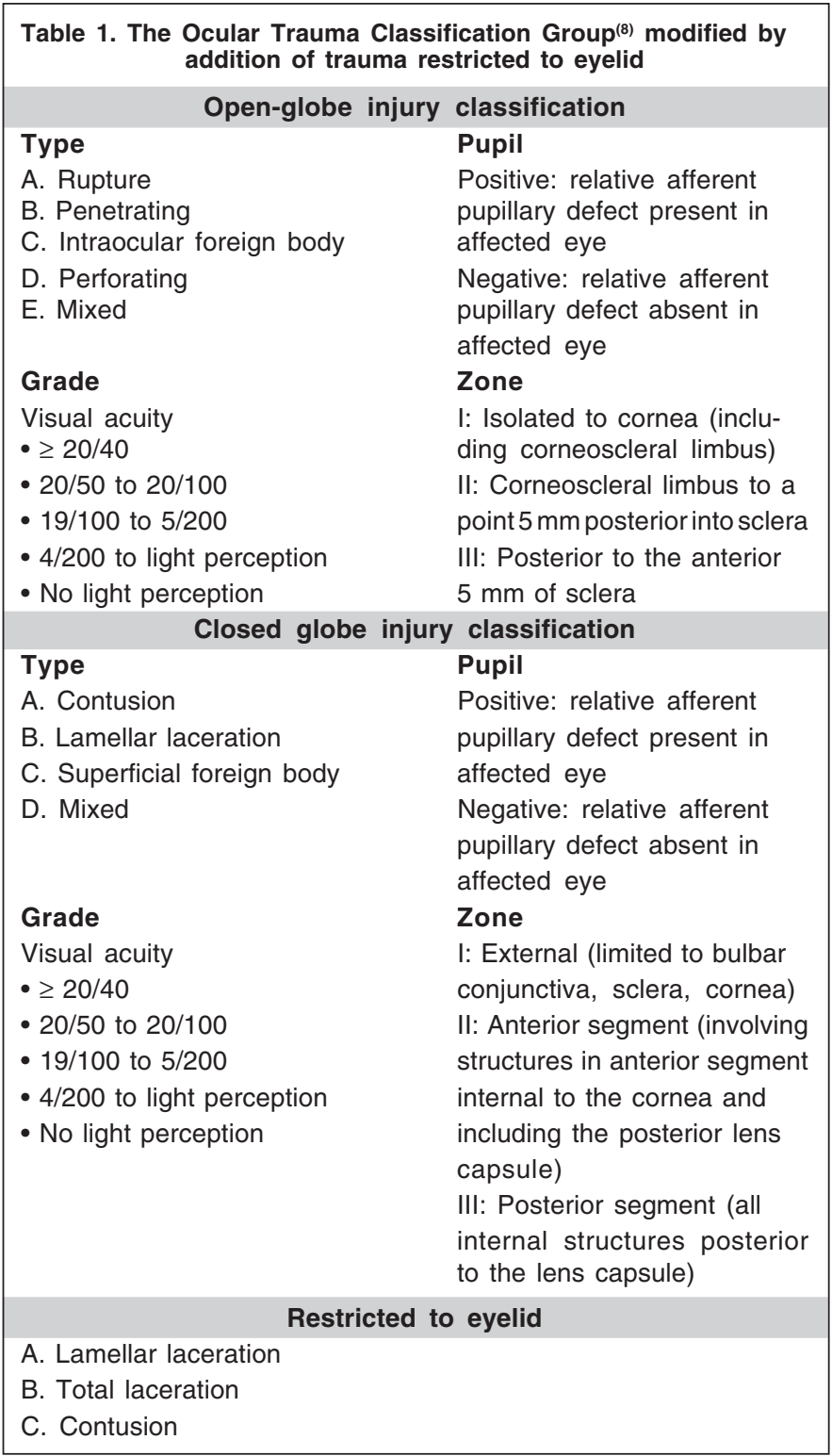

\section{RESULTS}

A total of 1,721 patients were admitted to the emergency room of the Department of Ophthalmology of the Federal University of São Paulo due to ocular trauma. Of these, 301 $(17.5 \%)$ were children under 16 years old. A total of 273 (90.7\%) patients were included in the study (28 patients [9.3\%] were excluded due to incomplete data).

Of the 273 children, 196 (71.8\%) were boys and 77 (28.2\%) were girls, with a male: female ratio of 2.5:1. Ages ranged from 1 to 15 years. Mean age was $7.97 \pm 3.85$ years. Most cases (39.9\%) belonged to the schoolchildren age group (7 to 10 years), followed by preschoolers (30.0\%), adolescents $(26.0 \%)$ and infants $(4.1 \%)$.

The right eye was involved in $139(50.9 \%)$ children, the left eye in $131(48.0 \%)$ and both eyes in $3(1.1 \%)$ children. The interval between accident and the admission to the hospital was up to 6 hours in $101(37.0 \%)$ patients, from 7 to 23 hours in $40(14.7 \%)$, from 24 hours to 5 days in 106 (38.8\%), from 6 to 10 days in $12(4.4 \%)$ and more than 10 days in $14(5.1 \%)$ patients. One hundred and twenty (44.0\%) patients had already sought previously another medical service, and $11(4.0 \%)$ two or more services, generally hospitals without ophthalmologists. The largest number of accidents occurred during the fourth quarter of year $(28.2 \%)$ followed by the third $(27.5 \%)$ ( Figure 1 ).

The mechanisms of ocular injury are shown in table 2 . The main cause was traumatism by external agents like stone, iron or wood $(28.9 \%)$, generally thrown by another child. Accidents with household items and leisure objects were also frequent ( $21.6 \%$ and $16.9 \%$ respectively). The injuries occurred most frequently at home (145 patients, $53.1 \%$ ), followed by leisure area (74 patients, $27.1 \%$ ), school (33 patients, $12.1 \%$ ) and road traffic (6 patients, $2.2 \%$ ). The site of injury was not recorded in $15(5.5 \%)$ patient files.

Diagnosis classification according to the Modified Ocular Trauma Classification Group $^{(8)}$ is shown in table 3. Injuries restricted to the eyelid occurred in $36(13.2 \%)$ accidents, closed globe injury occurred in $201(73.6 \%)$ and open globe injury in 36

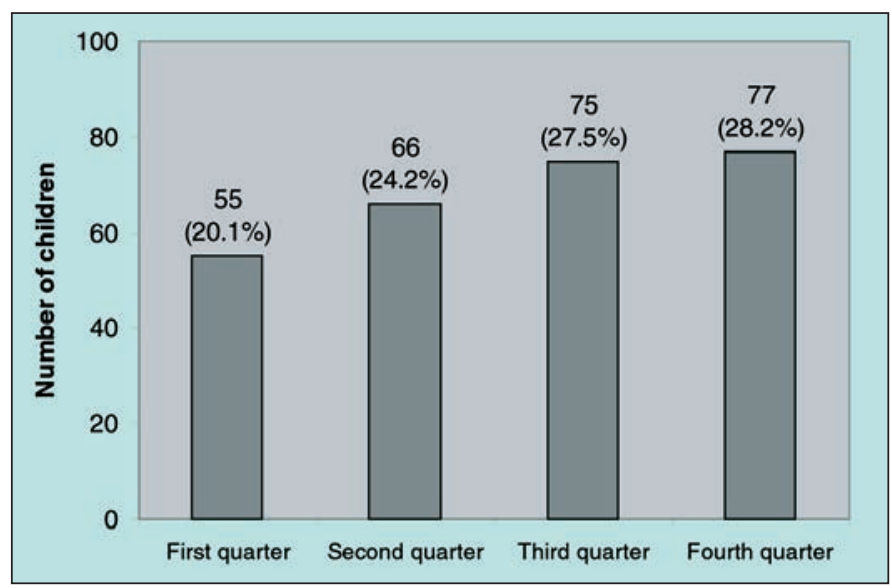

Figure 1 - Quarterly breakdown of injuries by number of patients chart 


\begin{tabular}{|c|c|c|c|c|c|}
\hline Mechanism of injury & $\begin{array}{c}\text { Under } 2 \text { years } \\
n(\%)\end{array}$ & $\begin{array}{c}\text { From } 2 \text { to } 6 \text { years } \\
n(\%)\end{array}$ & $\begin{array}{c}\text { From } 7 \text { to } 10 \text { years } \\
n(\%)\end{array}$ & $\begin{array}{c}\text { From } 11 \text { to } 15 \text { years } \\
n(\%)\end{array}$ & $\begin{array}{l}\text { Total } \\
\text { n (\%) }\end{array}$ \\
\hline External made of: & $1(9.1 \%)$ & $23(28.1 \%)$ & $36(33.1 \%)$ & $19(26.8 \%)$ & $79(28.9 \%)$ \\
\hline Stone & $1(9.1 \%)$ & $6(7.4 \%)$ & $17(15.6 \%)$ & $9(12.8 \%)$ & $33(12.0 \%)$ \\
\hline Metal & 0 & $7(8.5 \%)$ & $8(7.4 \%)$ & $4(5.6 \%)$ & $19(7.0 \%)$ \\
\hline Wood & 0 & $7(8.5 \%)$ & $8(7.4 \%)$ & $3(4.2 \%)$ & $18(6.6 \%)$ \\
\hline Glass & 0 & $3(3.7 \%)$ & $3(2.7 \%)$ & $3(4.2 \%)$ & $9(3.3 \%)$ \\
\hline Household items: & $4(36.4 \%)$ & $24(29.3 \%)$ & $18(16.5 \%)$ & $13(18.3 \%)$ & $59(21.6 \%)$ \\
\hline Mobile phones & $2(18.2 \%)$ & $10(12.4 \%)$ & $5(4.6 \%)$ & $1(1.4 \%)$ & $18(6.6 \%)$ \\
\hline Footwear & 0 & 0 & $1(0.9 \%)$ & $1(1.4 \%)$ & $2(0.7 \%)$ \\
\hline Broom & 0 & $2(2.5 \%)$ & $1(0.9 \%)$ & $1(1.4 \%)$ & $4(1.4 \%)$ \\
\hline Key & 0 & $3(3.6 \%)$ & 0 & 0 & $3(1.1 \%)$ \\
\hline Cutlery & $1(9.1 \%)$ & $3(3.6 \%)$ & $4(3.7 \%)$ & $4(5.6 \%)$ & $12(4.4 \%)$ \\
\hline Scissors & 0 & $3(3.6 \%)$ & $2(1.8 \%)$ & 0 & $5(1.8 \%)$ \\
\hline Other & $1(9.1 \%)$ & $3(3.6 \%)$ & $5(4.6 \%)$ & $6(8.5 \%)$ & $15(5.6 \%)$ \\
\hline Leisure items: & $1(9.1 \%)$ & $9(11.0 \%)$ & $19(17.4 \%)$ & $17(24.0 \%)$ & $46(16.9 \%)$ \\
\hline Ball & 0 & $1(1.2 \%)$ & $3(2.7 \%)$ & $9(12.8 \%)$ & $13(4.8 \%)$ \\
\hline Slingshot & 0 & $1(1.2 \%)$ & $6(5.5 \%)$ & $3(4.2 \%)$ & $10(3.7 \%)$ \\
\hline Toys & 0 & $6(7.4 \%)$ & $6(5.5 \%)$ & $2(2.8 \%)$ & $14(5.1 \%)$ \\
\hline Bicycle & $1(9.1 \%)$ & $1(1.2 \%)$ & $4(3.7 \%)$ & $3(4.2 \%)$ & $9(3.3 \%)$ \\
\hline Fall & $1(9.1 \%)$ & $6(7.3 \%)$ & $11(10.1 \%)$ & $3(4.2 \%)$ & $21(7.7 \%)$ \\
\hline Aggression & $1(9.1 \%)$ & $2(2.4 \%)$ & $6(5.5 \%)$ & $8(11.2 \%)$ & $17(6.3 \%)$ \\
\hline School material: & 0 & $5(6.1 \%)$ & $6(5.5 \%)$ & $1(1.4 \%)$ & $12(4.4 \%)$ \\
\hline Pencil & 0 & $4(4.9 \%)$ & $4(3.7 \%)$ & $1(1.4 \%)$ & $8(2.9 \%)$ \\
\hline Rubber band & 0 & $1(1.2 \%)$ & $1(0.9 \%)$ & 0 & $3(1.1 \%)$ \\
\hline Pencil sharpener & 0 & 0 & $1(0.9 \%)$ & 0 & $1(0.4 \%)$ \\
\hline Animal: & 0 & $5(6.1 \%)$ & $1(0.9 \%)$ & $3(4.3 \%)$ & $9(3.3 \%)$ \\
\hline Dog bite & 0 & $4(4.9 \%)$ & $1(0.9 \%)$ & $3(4.2 \%)$ & $8(2.9 \%)$ \\
\hline Cat scratch & 0 & $1(1.2 \%)$ & 0 & 0 & $1(0.4 \%)$ \\
\hline Motor vehicle & 0 & $2(2.4 \%)$ & $2(1.8 \%)$ & $1(1.4 \%)$ & $5(1.8 \%)$ \\
\hline Fireworks & 0 & $2(2.4 \%)$ & $1(0.9 \%)$ & $2(2.8 \%)$ & $5(1.8 \%)$ \\
\hline No data & $3(27.2 \%)$ & $4(4.9 \%)$ & $9(8.3 \%)$ & $4(5.6 \%)$ & $20(7.3 \%)$ \\
\hline Total & $11(100.0 \%)$ & $82(100.0 \%)$ & $109(100.0 \%)$ & 71 (100.0\%) & $273(100.0 \%)$ \\
\hline
\end{tabular}

\begin{tabular}{|c|c|c|c|c|}
\hline Classification & n (\%) & n (\%) & n (\%) & Total n (\%) \\
\hline Restricted to the eyelid: & --- & -- & --- & \\
\hline Total laceration & --- & --- & --- & $9(3.3 \%)$ \\
\hline Lamellar laceration & --- & --- & --- & $5(1.8 \%)$ \\
\hline Contusion & --- & --- & --- & $22(8.1 \%)$ \\
\hline Subtotal & --- & --- & --- & $36(13.2 \%)$ \\
\hline Closed globe: & Zone I & Zone II & Zone III & \\
\hline Contusion & $81(29.7 \%)$ & $30(11.0 \%)$ & $37(13.5 \%)$ & $148(54.2 \%)$ \\
\hline Lamellar laceration & $35(12.8 \%)$ & $1(0.4 \%)$ & 0 & $36(13.2 \%)$ \\
\hline Superficial foreign body & $2(0.7 \%)$ & 0 & 0 & $2(0.7 \%)$ \\
\hline Mixed & $1(0.4 \%)$ & $4(1.4 \%)$ & $10(3.7 \%)$ & $15(5.5 \%)$ \\
\hline Subtotal & $119(43.6 \%)$ & $35(12.8 \%)$ & $47(17.2 \%)$ & 201 (73.6\%) \\
\hline Open globe: & Zone I & Zone II & Zone III & \\
\hline Rupture & $2(0.7 \%)$ & $2(0.7 \%)$ & $2(0.7 \%)$ & $6(2.1 \%)$ \\
\hline Penetrating & 12 ( $4.4 \%)$ & $9(3.4 \%)$ & $3(1.1 \%)$ & $24(8.9 \%)$ \\
\hline Intraocular foreign body & $2(0.7 \%)$ & 0 & $1(0.4 \%)$ & $3(1.1 \%)$ \\
\hline Perforating & 0 & 0 & 0 & 0 \\
\hline Mixed & 0 & $2(0.7 \%)$ & $1(0.4 \%)$ & $3(1.1 \%)$ \\
\hline Subtotal & 16 ( $5.8 \%)$ & $13(4.8 \%)$ & 7 ( $2.6 \%)$ & 36 (13.2\%) \\
\hline
\end{tabular}


(13.2\%) accidents. Visual acuity was not recorded in 54 children $(19.7 \%)$, most of whom had suffered contusions to the globe. Visual acuity was better than 20/40 in 173 (63.4\%) children. Table 4 lists the type of injury according to visual acuity.

One hundred and seven children $(39.2 \%)$ were assisted using only general measures like pressure patching, warm or cold compresses or lubricant eye drops. Seventy-six patients $(27.8 \%)$ received medications such as antibiotics, cycloplegics or corticoids and were followed-up in the emergency service itself. In forty-eight patients $(17.6 \%)$ surgical management was required. Twenty patients $(7.3 \%)$ were referred to the out-department of some subspecialty and $22(8.1 \%)$ were referred to the specific ocular trauma out-department.

\section{DISCUSSION}

Many studies have shown that boys tend to be affected more commonly than girls, with male-female ratio varying from $2: 1$ to $4: 1^{(9-13)}$. In our study we found a male-female ratio of 2.5:1. These data are presumably due to the great physical contact, more adventurous or aggressive behavior of young boys, mostly in leisure activities. The school age group was more susceptible than other groups. It is believed that children in this age group are more independent than the younger but more immature than the older, what may make them more vulnerable ${ }^{(4,14)}$. The lower incidence of ocular trauma in infants (under 2 years old) can be explained by the parents' greater protection, the children's less independence and risk situations.

Regarding seasonal distribution, Will Eye Hospital's studies $^{(3,15)}$ described highest prevalence of ocular trauma during hot months (April to September in the northern hemisphere). In our study we did not observe any difference between the occurrences of trauma during hot or cold months. In the tropical climate of our country with its less well-marked seasons, winter temperatures are not low enough to account for restriction of activities.

We observed that $48.3 \%$ of patients waited more than $24 \mathrm{~h}$ to seek medical assistance. This delay can presumably worsen the prognosis. Forty-eight percent of the children had sought other services previously; most of them in general hospitals without ophthalmologic assistance. This could also have added to the delay of instituting adequate measures.
Data in the literature found a great percentage of traumas with missiles which generally occurred during child recreation $^{(11,15-16)}$. Other studies found high prevalence of ocular traumatism in sport-related activity ${ }^{(15,17)}$, like baseball, tennis and basketball. Perhaps sport-related eye injuries were not frequent in our study due to economic conditions of the population treated in our service. These children, bereft of access to sport practice, tend to improvise playthings with objects that could increase the risk of ocular traumatism. The lower prevalence of ocular trauma related to car accidents $(1.9 \%)$ could be explained by the success of the road traffic legislation implemented in Brazil in 1998 which orders to carry children in the rear seat and to use seat belts, although Brazilian data on this subject are controversial ${ }^{(18-19)}$. Furthermore, most of our patients belong to families who do not own a car.

We found that a significant number of injuries resulted from play with ordinary household items. We agree with other authors $^{(11,15,17)}$ that these causes of injury are potentially preventable. Educational measures should be taken to guide parental supervision and to clarify potential risks related to objects within the reach of the child ${ }^{(20)}$. Political and social measures for creation of more leisure areas and larger access of the population to organized practice of sports and to the education would reduce the number of such lesions.

In all age groups, the commonest location for an injury was the home, accounting for more than $50 \%$ of all accidents. This information corresponds closely to other studies of ocular trau$\mathrm{ma}^{(9-10,12,17,21-23)}$ and reinforces the need for attention to domestic utensils or other potentially dangerous home objects.

The classification proposed by the Ocular Trauma Classification Group $^{(8)}$, adopted in our service since 1999, was used in this study. This is a classification system based on standard terminology and features of eye injuries at initial examination that have shown good correlation with prognosis. It is a simple, readily usable system with clinical and research applications ${ }^{(8)}$. Having found $13.2 \%$ of the accidents restricted to the eye lid without injury to the globe, we decided to add this category to the classification.

A great proportion of closed globe injury (73.6\%), with predominance of contusion, which is in accordance with previous studies, was found ${ }^{(3,9,11,13,15,17)}$. Some authors point to superficial foreign body as the main cause of ocular trauma ${ }^{(24-27)}$.

\begin{tabular}{|c|c|c|c|c|}
\hline \multirow[b]{2}{*}{ Grade (visual acuity) } & \multicolumn{4}{|c|}{$\begin{array}{c}\text { Table 4. Type of injury and visual acuity (The Ocular Trauma Classification Group } \\
\text { Type of injury }\end{array}$} \\
\hline & Eyelid & Closed globe & Open globe & Total \\
\hline $1(\geq 20 / 40)$ & 25 (69.4\%) & $140(69.6 \%)$ & $8(22.2 \%)$ & $173(63.4 \%)$ \\
\hline $2(20 / 50$ to $20 / 100)$ & $0(0 \%)$ & $13(6.5 \%)$ & $2(5.5 \%)$ & $15(5.5 \%)$ \\
\hline $3(19 / 100$ to $5 / 200)$ & $0(\quad 0 \%)$ & $4(2.0 \%)$ & $2(5.5 \%)$ & $6(2.2 \%)$ \\
\hline $4(4 / 200$ to LP) & $0(0 \%)$ & $8(4.0 \%)$ & $16(44.5 \%)$ & $24(8.8 \%)$ \\
\hline 5 (NLP) & $0(0 \%)$ & $0(\quad 0 \%)$ & $1(2.8 \%)$ & $1(0.4 \%)$ \\
\hline Not recorded & $11(30.6 \%)$ & $36(17.9 \%)$ & 7 (19.5\%) & $54(19.7 \%)$ \\
\hline Total & $36(100 \%)$ & 201 ( $100 \%)$ & $36(100 \%)$ & $273(100 \%)$ \\
\hline
\end{tabular}


In our study the superficial foreign body trauma is underestimated because physicians tend to remove the foreign body without making a full file registration. Penetrating trauma was the most frequent kind of open globe injury.

\section{CONCLUSION}

Ocular trauma in childhood was more frequent in the male schoolchild and was due mostly to traumatism with agents like stone, wood and iron pieces, domestic utensils and leisure objects. The injuries occurred most frequently at home. Closed globe injuries predominated. Programs of education and prevention for ocular trauma in childhood are necessary.

\section{RESUMO}

Objetivo: Descrever os achados epidemiológicos do trauma ocular na infância em uma unidade de emergência. Métodos: Em estudo retrospectivo, foram analisados prontuários de pacientes menores que 16 anos que foram atendidos por trauma ocular no Pronto-Socorro de Oftalmologia da Universidade Federal de São Paulo de setembro de 2001 a setembro de 2004. Foram coletadas informações a respeito da idade, sexo, olho envolvido, local, circunstância e mecanismo do trauma, acuidade visual inicial e conduta imediata. Resultados: Um total de 273 pacientes foi incluído no estudo. A faixa etária com maior número de casos foi a de 7 a 10 anos $(39,9 \%)$. A causa mais freqüente de lesão ocular foi traumatismo com objetos externos como pedra, ferro ou madeira $(28,9 \%)$ e o local mais comum foi a própria casa $(53,1 \%)$. A acuidade visual inicial foi melhor que 20/40 em 63,4\% dos casos. Houve trauma ocular fechado em $201(73,6 \%)$ acidentes. Setenta e seis pacientes $(27,8 \%)$ foram tratadas com medicamentos e em quarenta e oito $(17,6 \%)$ casos foi necessário procedimento cirúrgico. Conclusão: $O$ trauma ocular na infância foi mais freqüente no sexo masculino, em escolares e foi associado a objetos tais como pedra, madeira, ferro, utensílios domésticos e brinquedos. Os acidentes aconteceram mais freqüentemente em casa e trauma fechado foi a lesão predominante. São necessários programas de educação e prevenção do trauma na infância.

Descritores: Traumatismos oculares/epidemiologia; Infância; Ferimentos oculares penetrantes; Serviço hospitalar de emergência

\section{REFERENCES}

1. Parver LM. Eye trauma: the neglected disorder. Arch Ophthalmol. 1986;104 (10):1452-3.
2. Erwin-Mulvey LD, Nelson LB, Freeley DA. Pediatric eye trauma. Pediatr Clin North Am. 1983;30(6):1167-83.

3. Nelson LB, Wilson TW, Jeffers JB. Eye injuries in childhood: demography, etiology, and prevention. Pediatrics. 1989;84(3):438-41.

4. Strahlman E, Elman M, Daub E, Baker S. Causes of pediatric eye injures. A population based study. Arch Ophthalmol. 1990;108(4):603-6.

5. Ben Zina Z, Jamel F, Wissam K, Rym K, Mustapha A, Mohamed A, et al. [Ocular trauma in children: report of 136 cases]. Tunis Med. 2000;78(10):580-3. French.

6. Negrel AD, Thylefors B. The global impact of eye injuries. Ophthalmic Epidemiol. 1998;5(3):143-69. Comment in: Ophthalmic Epidemiol. 1998;5(3): 115-6.

7. Sucupira ACSL, Werner Jr. J, Resengue R. Desenvolvimento. In: Sucupira ACSL, Bricks LF, Kobinger MEBA, Saito MI, Zuccolotto SMC. Pediatria em consultório. 4a ed. São Paulo: Sarvier; 2000. p.24.

8. Pieramici DJ, Sternberg P Jr, Aaberg TM Sr, Bridges WZ Jr, Capone A Jr, Cardillo JA, et al. A system for classifying mechanical injuries of the eye (globe). The Ocular Trauma Classification Group. Am J Ophthalmol. 1997; 123(6):820-31. Comment in: Am J Ophthalmol. 1998;125(4):565-6.

9. Diniz MC, Tzelikis PFM, Alvin HS, Gonçalves RM, Rodrigues A Jr., Trindade FC. Trauma ocular em criança abaixo de 15 anos: prevenção baseada em estatísticas. Rev Bras Oftalmol. 2003;62(2):96-101.

10. Cardoso GCL, Lima D, Escarião PHG, Reinaldo RE, Cavalcanti R. Trauma ocular na infância e adolescência. Rev Bras Oftalmol. 2002;61(2):131-5.

11. LaRoche GR, McIntyre L, Schertzer RM. Epidemiology of severe eye injuries in childhood. Ophthalmology. 1988;95(12):1603-7.

12. Luff AJ, Hodgkins PR, Baxter RJ, Morrell AJ, Calder I. Aetiology of perforating eye injury. Arch Dis Child. 1993;68(5):682-3.

13. Silva RE, Nassaralla BRA. Prevalência de trauma ocular infantil no ambulatório de SUS do Instituto de olhos de Goiânia. Rev Bras Oftalmol. 1998;57(11):865-8.

14. Rapoport I, Romem M, Kinek M, Koval R, Teller J, Belkin M, et al. Eye injuries in children in Israel. A nationwide collaborative study. Arch Ophthalmol. 1990;108(3):376-9.

15. Grin TR, Nelson LB, Jeffers JB. Eye injuries in childhood. Pediatrics. 1987; 80(1):13-7. Comment in: Pediatrics. 1991;88(2):420.

16. Tarelo-Saucedo A, Salinas Van Orman E. Traumatismo ocular infantil en poblacion mexicana: incidencia, manejo y resultado visual final. Rev Mex Oftalmol. 2001;75(1):1-4.

17. MacEwen CJ, Baines P, Desai P. Eye injuries in children: the current picture. Br J Ophthalmol. 1999;83(8):933-6.

18. Soriano ES, Souza LB, Moraes NSB, Freitas D. Incidência de perfuração ocular em acidentes automobilísticos pré e pós implantação da lei de obrigatoriedade do uso do cinto de segurança na cidade de São Paulo. Arq Bras Oftalmol. 1996; 59:382.

19. Silber PC, Souza LB, Tongu MTS. Perfil epidemiológico do trauma ocular penetrante antes e após o novo código de trânsito. Arq Bras Oftalmol. 2002; 65(4):441-4.

20. Kara-José N, Alves MR, Oliveira PR. Como educar a população para a prevenção do traumatismo ocular. Arq Bras Oftalmol. 1992;55(4):160-2.

21. Boudon AF, Souza LB, Moraes NSB, Freitas D. Perfuração ocular: estudo de 473 casos. Arq Bras Oftalmol. 1994;57(1):62-5.

22. Bison SHD, Reggi JRA. Traumas oculares: nosologia de 1.171 casos. Arq Bras Oftalmol. 1995;58(2):105-11.

23. Moreira CA Jr, Debert-Ribeiro M, Belfort R Jr. Epidemiological study of eye injuries in Brazilian children. Arch Ophthalmol. 1988;106(6):781-4.

24. Araújo AAS, Almeida DV, Araújo VM, Góes MR. Urgência Oftalmológica: corpo estranho ocular ainda como principal causa. Arq Bras Oftalmol. 2002; 65(2):223-7.

25. Leal FAM, Silva e Filho AP, Neiva DM, Learth JCS, Silveira DB. Trauma ocular ocupacional por corpo estranho superficial. Arq Bras Oftalmol. 2003;66 (1):57-60.

26. Cardoso GCDL, Torres IAOA, Almeida AMR, Ventura AGGM, Cavalcanti R. Fatores envolvidos no trauma ocupacional. Rev Bras Oftalmol. 2002;61(5): 357-61.

27. Andrade AS, Bisneto OS, Moreira H, Moreira CA. Traumas oculopalpebrais no serviço de pronto-atendimento oftalmológico do Hospital Universitário Evangélico de Curitiba. Arq Bras Oftalmol. 1999;62(5):585-9. 